T. Bui

\title{
TAX EVASION IN UKRAINE: CORPORATE AND PERSONAL LIABILITY
}

The paper aims to clarify and determine the definition of liability for tax evasion (financial, administrative. and criminal); to identify the main legal and financial problems of different types of liability in Ukraine; to define possible ways of solving these problems based on the law and economics theory and foreign legal experience of the countries that have already implemented corporate liability for tax evasion (the USA, the UK). The study investigates the gaps in legislation that enable tax violations and do not motivate corporations and managers to deter crime, including the uncertainty of legislation on types of liability and its non-compliance with international practice; a low level of fines for tax violations and a low level of criminal liability qualification; absence of corporate liability for tax evasion, which is essential to deter crimes; the lack of reporting and whistleblowing due to the low security level.

It is grounded that the range measures has to be taken to reduce the number of tax offences and increase the effectiveness of tax penalties in Ukraine. It is necessary to create preconditions for financial and administrative liability application instead of criminal liability. There is a need for introducing a strict corporate administrative and criminal liability for tax evasion. The government has to increase the limits of criminal liability since they are too low compared to international practice. The strong legislative system of whistleblowers' protection is needed to ensure the reporting of wrongdoings.

Keywords: tax evasion, financial offense, corporate liability, personal liability, criminal liability, financial liability, penalty, sanction, whistleblowing.

\section{JEL classification: H26, K14, K34}

Introduction and the research problem. Tax evasion is considered by the state as a serious violation of legislation and is subject to punishment. The most prosecuted tax evasion actions in Ukraine are failure to file, filing false data and tax reports, business relations with fictitious companies and tax "loopholes", overstatement of the tax credit, export reimbursement of VAT, tax evasion through bankruptcy procedure, etc.

Responsibility of taxpayers for violation of the tax legislation is provided in Chapter 11 of the Tax Code of Ukraine. According to Article 109 of Tax Code, tax offences are "unlawful acts (actions or inactions) of taxpayers, tax agents and / or their officials, as well as officials of the controlling authorities, which led to non-fulfillment or improper fulfillment of the requirements established by the legislation". Article 111 of the Tax Code stipulates that "the following types of legal responsibility can be applied in case of violation of taxation law: financial; administrative; criminal. Financial liability is applied in the form of fines and penalties." In case of tax evasion financial liability means the fines and penalties imposed on companies and individuals directly by the State Fiscal Service of Ukraine without litigation. However, today none of the three types of liability meet international standards and provide effective protection against crime and corruption committed by corporate representatives.

Resent publications analysis. Corporate responsibility is mostly a subject of American scientists' researches, namely Jennifer Arlen's, Cindy R. Alexander's, Mark A. Cohen's, Alan Sykes's, W. Bentley MacLeod's, Reinier Kraakman's. Scientific works of Ukrainian scientists A. Krysovatyi, V. Oparin, T. Koschuk, T. Paentko are devoted to the research of tax evasion. The problems of implementing corporate liability in Ukraine are somehow reflected in the articles of D. Kamensky, A.Yarmola, M. Sysoiev. Ukrainian law and economics scientists D. Fedorchuk and D. Foremnyi investigated the problem of whistleblower protection and its influence on Ukrainian business. The greatest success in the study of corporate liability for tax evasion is reached by the tax agencies of the USA, the UK, the Netherlands, and Germany. 
Unsolved parts of the problem. The current legal framework of Ukraine is ineffective and incapable of combating tax evasion. At the same time, businesses suffer from excessive pressure of the fiscal service and a large number of criminal cases of tax evasion. There are many legal and economic problems of liability for tax evasion that have to be investigated, including the uncertainty of legislation on types of liability and its non-compliance with international practice, in particular the application of so-called financial liability (which essentially is administrative or civil); a low level of fines for tax violations and a low level of criminal liability qualification; the absence of corporate liability for tax evasion which is essential to deter crimes; a lack of reporting and whistleblowing due to the low security level.

Research goal and questions. The article aims to clarify the definition of liability for tax evasion, to identify the main legal and financial problems of different types of liability in Ukraine, to define possible ways of solving these problems based on the law and economics theory and foreign legal experience.

Main findings. There is no definition of "financial offense" in the Tax Code, although this kind of liability is foreseen. Accordingly, there are no clearly defined elements of the offense for which financial liability can be applied. The legislative definition is a general, collective concept and can not be regarded as a definition of a particular financial offense. All tax offenses (Articles 117-128) contain a formal composition. To qualify for taxpayer actions, no adverse consequences are required, but only the mere fact of the offense proved. It means (and such an opinion is taken by the control bodies) that the amount of the fine does not depend on the presence or absence of the damage to the state budget, or by its size.

The other problem is a lack of an efficient procedure for administrative challenging of resolutions of the tax authorities in Ukraine. Ukrainian legislation envisages a procedure for administrative challenging of resolutions of an oversight authority in the form of filing the complaints to a superior authority or court appeals. Naturally, the procedure for administrative challenging is less costly than the court proceedings, whereas the claimant does not have to pay the court fees. At the same time, in practical terms, the administrative challenging procedure is totally ineffective in Ukraine [1].

Due to these reasons, taxpayers are forced to appeal to the courts to protect their rights and avoid the administrative appeal procedure as groundless. As a result, despite the fact that the Tax Code places the controlling authority under obligation to prove the validity of a ruling, the burden of proof is factually shifted to business entities.

The decisions of tax authorities should be supported by reasoned opinions in terms of criteria set by the European Court of Human Rights. Specifically, tax authorities must justify their decisions by providing proper grounds underlying such decisionmaking; each important argument of a taxpayer must be analyzed.

The number of criminal cases investigated in the sphere of tax legislation violations in Ukraine increases each year. According to the official data of the State Tax Service of Ukraine, in 2017 investigation of about 2000 criminal cases was completed by tax police officers with compensated damages. As a result, about UAH 700 million worth of damages were paid by the violators to the state budget. Nine out of every ten detected crimes are serious or especially serious crimes. The majority of the abovementioned criminal cases are connected to tax evasion.

The following persons may be the subject of a tax crime in Ukraine:

- an official person of the enterprise, institution, organization irrespective of the form of ownership;

- a person engaged in an entrepreneurial activity without creation of a legal entity;

- any other person obliged to pay taxes, fees, or other mandatory payments.

According to Article 212 of Criminal Code of Ukraine, the crime of tax evasion is defined as willful evasion of taxes, fees, or other mandatory payments which are a part of the taxation system established by law, by an officer of an enterprise, an institution or an organization of any ownership status, or by any person conducting entrepreneurial activity without establishment of a legal entity, or by any other person liable to pay such taxes, fees, or other mandatory payments, if such actions resulted in actual non-receipt of funds by budgets or special state funds.

The liability for tax evasion is to be applied only for intentional tax evasion. The intention for evasion of taxes can be indicated when tax accounting is missing or violated, in cases of distortion of data in accounting and reports, non-posting of cash received for services rendered and works performed, double accounting, use of bank accounts unknown to the tax authorities, overstating actual expenses, and so on. The motive of the crime does not play any role in qualification. 
Part 2 of Article 11, "The concept of crime" of the Criminal Code of Ukraine states the following: "An action or inaction although formally having signs of any offense under this Code, but because of insignificance does not make danger to the society that means has not caused and could not have caused significant damage to natural or legal persons, society or the state, does not considered as a crime." That is why determination of the appropriate limit at the legislative level is very important to determine the margin beyond which the actual crime begins.

The relevant provisions of the On Administrative Offenses Code of Ukraine can be applied in case of unintended violation of tax regulation. Articles 163-1 (violation of tax accounting, filing the audit reports), 163-2 (failure to file, untimely filing the payment order for paying taxes, fees or other mandatory payments), 163-4 (violation of holding, paying personal income tax and filing the relevant data) are often applied to such violators.

Section 4 of Article 212 of the Criminal Code of Ukraine stipulates the general rule for discharging from criminal liability under Article 212: a person who committed an act provided by this Article shall be discharged from criminal liability if he/she has paid taxes and fees (mandatory payments) and indemnified the state for the damage caused by late payment (fiscal penalties, fines) prior to holding such a person criminally liable.

The Criminal Code of Ukraine provides that damages resulting from the crime stipulated in Article 212 of the Criminal Code of Ukraine should be paid by the individual who committed the crime. Such payment is considered as compensation of losses caused by the crime and the suspect's positive post-crime behavior. In practice the damages are often paid by the company the suspect is working at. However, the compensation of losses before charges are brought, resulting in discharging from criminal liability, seems more attractive than paying the fine under a court sentence and damages under a civil law suit. In some cases the sum that someone convicted under Article 212 is obliged to pay under a court decision may double exceed the size of the sum in unpaid taxes.

Due to the excessive number of criminal investigations under Article 212 in Ukraine, the existing limits of criminal liability for tax evasion appear to be too low. Decreasing criminal proceedings by increasing the limits of criminal liability would reduce the unnecessary pressure on the economy and promote the investment and business climate in whole.
Currently, the Tax Code contains numerous grounds for conducting extraordinary tax audits of taxpayers. Recent amendments with regard to the moratorium on making such audits have turned to be inefficient and factually resulted in an increase of number of criminal proceedings. Any audit report containing an amount of additional payments in excess of a qualification limit as set out in article 212 of the Criminal Code of Ukraine is filed immediately with a tax police department for further criminal proceedings. It should be noted that opened criminal proceedings do not depend on whether a taxpayer has challenged such a tax notice (decision) or not. Such criminal proceeding provide the tax authorities with an opportunity to pursue extraordinary tax audits and inspections of taxpayer's counterparties without securing approval of the Cabinet of Ministers of Ukraine and are used mainly to squeeze a taxpayer [1].

The system of audits and the number of underlying reasons for such audits has to be reviewed and decreased, respectively. In addition, it would be appropriate to clearly state the individual responsibility of a taxpayer in the Tax Code and ban the deduction of amounts supported by tax invoices received from the so called doubtful counterparties from the amount of tax credit or loss.

Organization for Economic Cooperation and Development issued Guidelines on transfer pricing (2010) containing the review of practice of OECD member countries on measures to ensure the proper payment of taxes. Para. 4.20 of Section 4 "Administrative approaches" of the mentioned document states in particular that the criminal sanctions in almost all cases are assigned actually to cases on extra large evasions, and they usually involve very heavy burden of proof by the party that claims the existence of such evasion (i.e. by Tax Administration). Criminal sanctions do not refer to the main tools for ensuring compliance with the tax legislation in any member countries of the Organization for Economic Cooperation and Development. Civil (or administrative) liability is a more common tool.

In Ukraine almost each fact of additional charge of tax over the established limit leads to automatic opening of criminal proceeding. It goes so according to the methodical recommendations of the State Fiscal Service of Ukraine as of sending respective notifications to investigation bodies and provisions of the Code of Criminal Procedure of Ukraine as of automatic opening of proceeding in case of receiving such notifications. Even if respective investigation does not result in transmission of a case to the 
court, as a rule, it itself creates unfavorable consequences for the taxpayer through the factual pressure and real obstruction of their business activity. Opening of a criminal proceeding gives tax authorities a very powerful leverage of influence on taxpayers: in order to close a criminal case many entrepreneurs voluntarily agree to pay tax accrued even if its validity raises certain doubts.

Article 212 "Tax evasion" of the Criminal Code of Ukraine prescribes the liability for the intended tax evasion if the respective actions resulted in the actual non-receipt of funds to the budget or to the state trust funds in a considerable amount (Part 1 of the Article), a large amount (Part 2 of the Article), and an especially large amount (Part 3 of the Article). These amounts are related to the quantity of "tax-free minimum incomes" (Table 1).

Under the considerable amount one shall understand the amount of taxes, charges, and other obligatory payments which exceed the prescribed by the legislation tax-free minimum incomes in a thousand or more times (a large amount -3000 tax-free minimum incomes, an especially large amount -5000 tax-free minimum incomes).
During the last few years, the amount of the taxfree minimum income did not increase in proportion to the change of other economic indicators, such as the inflation rate and the currency exchange rate. As a result, in 2017 the limit for qualification under Article 212 of the Criminal Code of Ukraine is equivalent to USD 29,963 (UAH 800,000) according to the official currency rate of the National Bank of Ukraine, which is very low comparatively to international experience.

Financial and criminal sanctions for tax evasion in Ukraine are too low to deter offenses (Table 2). Administrative sanctions are even lower than criminal sanctions. The economics and law theory proved that the government can only deter crimes with a fine that exceeds the benefit from committing the crime if the crime may escape detection and sanctions, which is the case in Ukraine (the probability of sanctions is much less than 1). Sanctions for tax evasion should be higher the greater the incentive to commit crime and the lower the probability of detection [2].

In the Netherlands the highest penalty for tax evasion is 79,000 Euros, while in Ukraine this figure is only about 15,000 Euros (UAH 425,000).

Table 1. Qualification of criminal liability for tax evasion in Ukraine

\begin{tabular}{|l|c|c|c|c|c|c|c|}
\hline \multicolumn{2}{|c|}{ Indicators } & $\mathbf{2 0 1 3}$ & $\mathbf{2 0 1 4}$ & $\mathbf{2 0 1 5}$ & $\mathbf{2 0 1 6}$ & $\mathbf{2 0 1 7}$ & $\mathbf{2 0 1 8}$ \\
\hline $\begin{array}{l}\text { Amount of tax-free minimum income } \\
\begin{array}{l}50 \% \text { of minimum poverty line for } \\
\text { employable person) }\end{array}\end{array}$ & UAH & 573,5 & 609 & 609 & 689 & 800 & 881 \\
\cline { 2 - 9 } & USD & 71,7 & 76,1 & 38,5 & 28,9 & 30 & 31 \\
\hline $\begin{array}{l}\text { Qualification under part 1 of the } \\
\text { Criminal Code of Ukraine }\end{array}$ & UAH & 573500 & 609000 & 609000 & 689000 & 800000 & 881000 \\
\cline { 2 - 9 } & USD & 71688 & 76125 & 38544 & 28950 & 29963 & 31385 \\
\hline $\begin{array}{l}\text { Qualification under part 2 of the } \\
\text { Criminal Code of Ukraine }\end{array}$ & UAH & 1720000 & 1827000 & 1827000 & 2067000 & 2400000 & 2643000 \\
\cline { 2 - 9 } & USD & 215000 & 228375 & 115633 & 86849 & 89552 & 94157 \\
\hline $\begin{array}{l}\text { Qualification under part 3 of the } \\
\text { Criminal Code of Ukraine }\end{array}$ & UAH & 2867500 & 3045000 & 3045000 & 3445000 & 4000000 & 4405000 \\
\cline { 2 - 8 } & USD & 358438 & 380625 & 192722 & 144748 & 149254 & 156929 \\
\hline
\end{tabular}

Source: calculated based On the Law on the State Budget and Criminal Code of Ukraine according to official currency exchange rate of the National Bank of Ukraine in January.

Table 2. Penalties for criminal liability for tax evasion in Ukraine

\begin{tabular}{|c|c|c|}
\hline Type of crime & Penalties & Additional punishment \\
\hline $\begin{array}{l}\text { considerable } \\
\text { amount }\end{array}$ & $\begin{array}{l}\text { fine from UAH } 17000 \\
\text { to UAH } 34000\end{array}$ & \\
\hline large amount & $\begin{array}{l}\text { fine from UAH } 34000 \\
\text { to UAH } 51000\end{array}$ & $\begin{array}{l}\text { deprivation of the right to occupy certain positions or engage in } \\
\text { certain activities for a term of up to } 3 \text { years }\end{array}$ \\
\hline $\begin{array}{l}\text { especially large } \\
\text { amount }\end{array}$ & $\begin{array}{l}\text { fine from UAH } 225000 \\
\text { to UAH } 425000\end{array}$ & $\begin{array}{l}\text { deprivation of the right to occupy certain positions or engage in cer- } \\
\text { tain activities for a term of up to } 3 \text { years and property confiscation }\end{array}$ \\
\hline
\end{tabular}

Source: calculated based on the Law On the State Budget and Criminal Code of Ukraine. 
It means that the fine for tax avoidance in an especially large amount can be 10 times lower than an expected benefit of the company's owner. Financial penalties must be high enough and structured in such a way that corporations face lower expected costs when they pay taxes according to the law than when they do not [3].

It is worth noting that only financial responsibility can be applied to the legal entity (corporation) in Ukraine. The other two types of responsibility (administrative and criminal) relate only to individuals. But tax avoidance is a clear case when the state cannot impose a sufficient sanction to deter corporate crime through individual liability alone due to certain objective reasons:

- benefit of crime is usually large and the probability of detection is small;

- in most cases the owner of the business is a real beneficiary of tax evasion, but in case of individual liability the director or the chief accountant are liable for offense;

- if complicated tax schemes are built, it is hard to find a real responsible person and hard to prove the intent.

Actions of corporate managers and owners that give subordinate orders to sign or submit fake reports, do not pay taxes or pay them not in full, are qualified by Article 212 of the Criminal Code of Ukraine as complicity in a crime. In reality participation of the chief accountant in tax evasion is usually easy to prove, but the link to tax evasion of the director or other beneficiaries is subject to proof, and, as practice shows, investigators do not always manage to cope with this task.

There is no corporate criminal or administrative liability for tax evasion in Ukraine. Many Ukrainian scholars remain skeptical about the mere justification of corporate criminal liability. Some of them conclude that the American concept of corporate criminal liability demonstrates a serious deviation from the established doctrines of corpus delicti and mens rea, while shifting liability from real actors - natural persons - to artificial legal entities. But the issue of personal versus organizational liability has long since been resolved in many countries to support the latter, thus pursuing the goal of more effectively prosecuting serious wrongdoing that takes place in corporate offices. The American record in enforcing corporate criminal liability has proved to be effective in restoring public confidence in a strong government holding businesses accountable for their illegal actions. As for the innocent shareholders and customers, numerous studies have demonstrated that damage to such persons is exaggerated [4].

Upon introduction of this type of liability to the criminal law of any country, as is currently the case with Ukraine, detailed guidelines for prosecutors and judges need to be issued to ensure both the responsible and effective use of the newly created statutory provisions. Today many experts agree with the suggestion that a balanced application of wellwritten organizational criminal liability standards empowers prosecutorial and judicial communities with higher integrity, professional responsibility, and impartiality - the qualities that are always important when dealing with a powerful corporate world.

Among European countries, the UK can serve as a case for Ukraine. In recent years, the UK has sought to reform this area of law, including by adopting a new type of offence, criminalising a corporate for "failure to prevent" a criminal offence being committed. This type of offence imposes strict liability on an entity unless it can demonstrate it has certain preventative measures in place. The UK Parliament passed the Criminal Finances Act 2017 that introduces a new offence of failure to prevent the facilitation of tax evasion and grants the UK authorities additional powers to combat financial crime. This new offence is designed to revolutionise corporate attitudes to tax-sensitive activities, and places the onus on corporates to stop the persons who act for it, or on its behalf, from facilitating tax evasion wherever in the world it occurs. Corporates should prepare to undertake a risk assessment and implement prevention procedures (including enhancements to existing compliance policies and procedures) to mitigate a business risk arising from the new offence.

In Ukraine both administrative (civil) and criminal corporate liability have to be introduced for tax avoidance. Administrative sanctions are less expensive and have less negative consequences for the company's activities, so they should be applied to companies that monitor, investigate, and report taxes optimally. Criminal liability should be applied for large and especially large amounts of tax avoidance and for companies that do not monitor, report, and cooperate with tax authorities. 
An important obstacle to the introduction of effective liability for tax offenses is the lack of legislation on the whistleblowers protection in Ukraine.

In Resolution 1729 (2010) "The protection of "whistleblowers", the Parliamentary Assembly of the Council of Europe stressed the importance of "whistleblowing" as an opportunity to strengthen accountability and bolster the fight against corruption and mismanagement, both in the public and private sectors [5]. The US has launched an extended a whistleblowers' protection and reward program as part of Wall Street reform in 2010 with the Dodd-Frank Act. As a result, the number of whistleblowing reports has since increased significantly. Companies have responded in different ways. Some became more closed and limited the access to the internal information for employees. Some updated their policies to minimize the opportunities for fraudulent activities. Still, studies show that most investigations in the US are based on the tips from whistleblowers. This is a good indicator of whistleblowing effectiveness in detecting and investigating corruption schemes and importance of adequate whistleblower protection laws [6].

However, in Ukraine persons informing the authorities on the misdeeds of officials or employers frequently face civil claims for compensation of moral damages (often exorbitant and punitive in nature) due to dissemination of defamatory or libelous statements.

Up to day Ukraine has established a consistent legal framework for protection of whistleblowers' reporting corruption-related offenses (the Principles of Prevention and Countering of Corruption Act No. 3206-VI of 7 April 2011; On Prevention of Corruption Act No. 1700-VII of 14 October 2014). Such persons are guaranteed anonymity and are protected against any employment-related sanctions. Additionally, the informants who file complaints with the responsible authorities are generally immune to defamation claims.

However, with regard to reporting to other office wrongdoings and accounts of mismanagement not readily falling within the ambits of corruption, as well as cases of public disclosure of non-corruption abuses (e.g., reporting abuses to journalists rather than to public authorities), the legal protection of informants still remains unclear and inadequate. It is only the ECHR jurisprudence which provides at least some guidance on the proper treatment of such cases. Taking into account that the channels for reporting abuse of the employer remain somehow exotic in Ukraine (existing primarily in the subsidiaries of Western companies), whistleblowers in the private sector remain, despite considerable recent legislative developments, vulnerable to retaliation, with no reliable remedies to defend themselves.

Conclusions. Consequently, there are a number of measures to take in order to reduce the number of tax offenses and increase the effectiveness of penalties for such offenses in Ukraine.

First, it is necessary to reform the legislative framework for financial and administrative liability and create the preconditions for their application instead of criminal liability which will be less costly and impose fewer reputational risks on companies. Financial penalties must be high enough and structured in such a way that corporations face lower expected costs when they pay taxes according to the law than when they do not.

Second, it is necessary to introduce corporate administrative and criminal liability for tax evasion. It is advisable that it were a strict liability, since in the case of tax evasion, corporations more often have a gain from committing an offense than individuals who actually commit it, and in most cases firms have no incentives to report crimes. Monetary sanctions should prevail over non-monetary ones, since it is cheaper and more effective for society.

Third, the government has to increase the limits of criminal liability, since they are too low comparatively to international practice. As a result, the quantity of criminal proceedings will decrease that will lower the costs and positively affect the operations of corporations.

Fourth, a strong legislative system of whistleblowers protection is needed to ensure the reporting of wrongdoings. It will create optimal conditions for corporations and individuals to monitor, investigate, and report tax avoidance.

\section{References}

1. Kalnytska, I. (2015). Tax reform in Ukraine - key challenges and possible solutions. Retrieved from https://taxlinked.net $/ \mathrm{m} /$ gvozdiy-oberkovych-law-firm/publications/tax-reform-inukraine-key-challenges-and-possible.
2. Alexander, C., Arlen, J., \& Cohen, M. (1999). Regulating Corporate Criminal Sanctions: Federal Guidelines and the Sentencing of Public Firms. The Journal of Law and Economics, 42, S1, 393-422. 
3. Arlen, J., \& Kahan, M. (2017). Corporate Governance Regulation Through Nonprosecution. The University of Chicago Law Review, 84, 323-387.

4. Kamensky, D. (2016). Introducing Corporate Criminal Liability in Ukraine: Terra Incognita. Stetson Law Review, $46,89-110$.
5. Fedorchuk, D. (2015). Whistleblower protection in Ukrainian private business. The Ukrainian Journal of Business Law, 12, 15-17.

6. Foremnyi, D. (2016). Will whistleblowing make Ukraine a better place for doing business? Compliance Periscope. Retrieved from http://complianceperiscope.com/home/2016/11/ 16/whistleblowing-in-ukraine-to-be-or-not-to-be

Буй Т. Г.

\section{УХИЛЕННЯ ВІД ОПОДАТКУВАННЯ В УКРАЇНІ: КОРПОРАТИВНА ТА ПЕРСОНАЛЬНА ВІДПОВІДАЛЬНІСТЬ}

Метою статті є пояснення і розмежування видів відповідальності за ухилення від оподаткування (фінансова, адміністративна і кримінальна відповідальність), визначення основних правових і фінансових проблем різних видів відповідальності за податкові правопорушення в Україні, а також формування пропозищій щодо розв'язання зазначених проблем на основі правового досвіду країн, які впровадили корпоративну відповідальність за ухилення від оподаткування (США, Велика Британія).

Стаття досліджуе прогалини в украӥнському законодавстві, які сприяють правопорушенням у податковій сфері та не мотивують підприємства і посадових осіб на боротьбу з податковоми злочинами. Зокрема, до таких прогалин належать невизначеність законодавства щодо видів відповідальності та їх невідповідність міжнародним нормам; занадто низький поріг кримінальної відповідальності за ухилення від оподаткування та низький рівень штрафних санкиій за податкові правопорушення; брак корпоративної відповідальності за ухилення від сплати податків в Україні, що є важливою передумовою для запобігання злочинам; нерозвиненість культури інформування про податкові правопорушення через низький рівень безпеки.

Обтрунтована необхідність впровадження заходів щодо зменшення кількості податкових правопорушень і підвищення ефективності податкових санкиій в Украйні, зокрема створення передумов для ширшого застосування фінансової та адміністративної відповідальності замість кримінальної; підвищення розміру штрафів за податкові правопорушення; запровадження корпоративної адміністративної та кримінальної відповідальності за ухилення від сплати податків; створення законодавчої бази захисту інформаиії та механізмів інформування та звітування про податкові правопорушення.

Ключові слова: ухилення від оподаткування, фінансовий злочин, корпоративна відповідальність, персональна відповідальність, кримінальна відповідальність, фінансова відповідальність, штраф, санкція, інформування про порушення. 